\title{
The Effect Of The Korean Wave On Nation Brand South Korea (Study On USU Physics Students)
}

\author{
Deninta Novienthia \\ Department of Commerce/Business Administration Science, University Of North Sumatra, Indonesia.
}

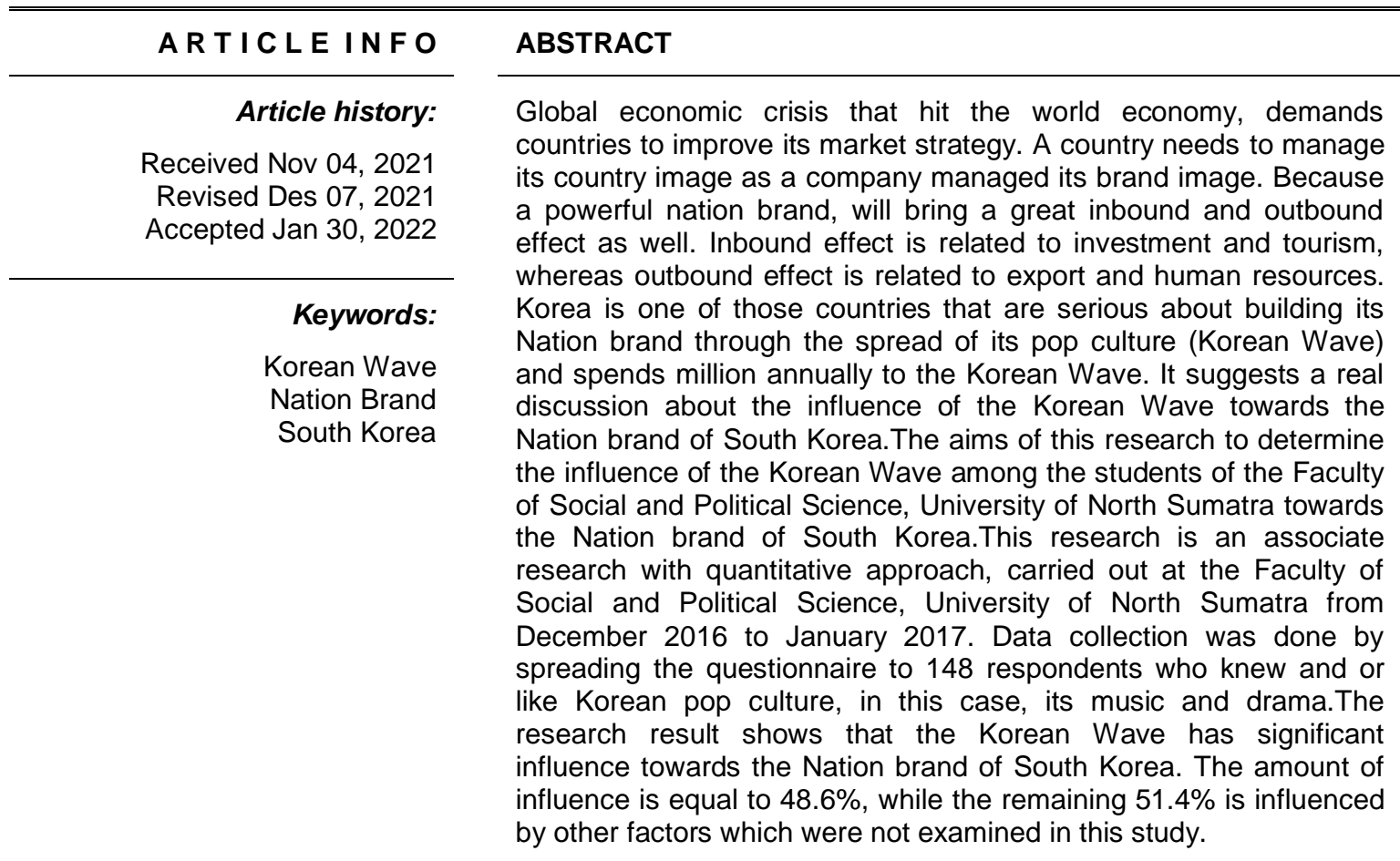

This is an open access article under the CC BY-NC license.

\section{Corresponding Author:}

Deninta Novienthia,

Department of Commerce/Business Administration Science,

University Of North Sumatra, Indonesia,

Jl. Dr. Mansur No. 9 Padang Bulan, Kec. Medan Baru, Kota Medan 20222.

Email: denintanovienthia@gmail.com

\section{INTRODUCTION}

Nation branding is a concept adopted from marketing principles which were first developed by Simon Anholt in the Journal of Brand Management in 1998 (Prost \& Bondaz, 2014:1). Nation branding discusses how much impact a product traded between countries has on the country's image, and is the overall perception of a nation in the eyes of the international public. When talking about a Nation brand, we talk about a brand of a country complete with its inherent attributes. For example, China, when talking about the Chinese Nation brand, the elements that build the Nation brand are the flag, the national anthem, tagline, culture and tourist attractions such as kung fu, pandas, and the great wall of China. or what is currently being discussed, namely the bird nest stadium in China, which is the first stadium in the world with a bird's nest as an architectural concept. If the product brand image at any time can be discontinued, modified, and/or remarketed, 
it is different from a nation brand. At the Nation brand, things like the above are difficult or even impossible to do.

A good nation branding will have a positive economic impact on the nation or country, especially with regard to exports and domestic trade. That is why it is important to study the extent to which branding has an impact on trade, tourism, and investment. The formation of a country's image, both internally and externally, is based on its positive values and perceptions. The purpose of Nation branding is to create a good country image so that it can attract investment, tourists, create jobs, and increase exports, and so on.

In 2012, to support this Nation branding project, the Ministry of Culture and Tourism Korea prepared a fund of 730 billion won or 6.2 million USD to build a new concert vanue, hold events, and provide financial support for Hallyu or the Korean Wave (David , 2015). Hallyu or Korean Wave is a term given to the spread of Korean pop culture (K-pop, K-drama) globally in various countries in the world which triggers many people in these countries to learn Korean language and culture. According to Euny Hong, author of The Birth of Korean Cool: How One Nation is Conquering the World Through Pop Culture, Korea spent billions of dollars to make the country the number one exporter of pop culture in the world.

Data for 2005 shows that the Korean Wave supports South Korea's GDP by $0.2 \%$. The Korean Wave supported US $\$ 1.8$ billion or 2.14 trillion won in the export and tourism sectors. In the category of selling local goods, the Korean Wave was able to contribute US $\$ 918$ billion. In more detail, the South Korean research institute said that the number of foreign tourists to South Korea increased from 647,000 people to 968,000 in 2004. The increase in tourists is due to the increasing number of people outside Korea who want to visit Korea because of Hallyu fever (Ikhsan \& Pinem, 2012). According to a report released in 2015 by the Hyundai Research Institute, exports of products directly related to Hallyu in countries affected by the Hallyu fever have increased compared to other export products. It accounts for $2.9 \%$ of Korea's total exports, making it an important part of the economy. Five product groups have been designated as Hallyu products by the Korea Custom Service, namely culture, living, food, clothing and accessories, home appliances, and computers (David, 2015).

This nation branding project has proven useful. Korea was ranked 27th in the Anholt-GfK Nation Brand Index (NBI) overall brand ranking in 2011 (Prost \& Bondaz, 2014: 3). Become a place worth visiting instead of a country that shuts itself off from the outside world and engages in war. South Korea is indeed one of the countries, if not the only country in the world, which has put so much effort in its nation branding strategy (Leong, 2014).

\section{RESEARCH METHOD}

This study uses associative research with a quantitative approach. That is research that seeks to examine how a variable is influenced by other variables. The analysis used in this research is simple linear regression analysis which will be analyzed with the help of statistical programs.

\subsection{Simple Linear Regression Analysis}

To predict the value of the independent variable $(X)$ if the value of the dependent variable $(Y)$ has increased or decreased and to determine whether the direction of the relationship between the independent variable and the dependent variable is positive or negative. The form of the simple linear regression equation used in this study is as follows:

$\mathrm{Y}=\mathrm{a}+\mathrm{bX}$

Information:

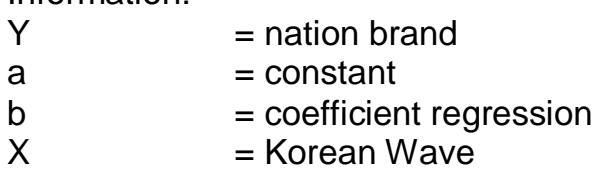

\subsection{Classic assumption test}


The classical assumption test will be processed using the SPSS 23.0 statistical application. The classical assumption test used in this study is the Normality Test. Testing the normality of the data is used to see whether in the regression model, the dependent variable and the independent variable have a normal distribution or not. If the data spreads around the diagonal line and follows the direction of the diagonal line, the regression model meets the assumption of normality. A good regression model is if the data distribution is normal.

\section{RESULTS AND DISCUSSIONS}

\subsection{Validity test}

Validity test is carried out to obtain valid or valid research instruments so that they are suitable for use as a measuring tool in research. The validity of the research instrument will be tested by comparing the correlation value (rcount) with rtable. The criteria for assessing the validity of each instrument statement are:

a. If rcount $>$ rtable, then the research instrument is declared valid.

b. If rcount $<$ rtable, then the research instrument is declared invalid.

The questionnaire consists of two types of variables, namely the independent variable (Korean Wave) which contains 6 statements and the dependent variable (Nation brand) which contains 15 questions. So, overall there are 21 questions in this research instrument. Questionnaires were distributed to 148 respondents who met the sampling criteria. For a significance level of $5 \%$ with degrees of freedom $\mathrm{df}=n-2$, the rtable value is 0.1614 .

Table 1. Free Variable Validity Test Results

\begin{tabular}{|c|c|c|c|c|c|c|c|c|}
\hline & & $\begin{array}{l}\text { Korean } \\
\text { Wave } 1\end{array}$ & $\begin{array}{l}\text { Korean } \\
\text { Wave } 2\end{array}$ & $\begin{array}{l}\text { Korean } \\
\text { Wave } 3\end{array}$ & $\begin{array}{l}\text { Korean } \\
\text { Wave } 4\end{array}$ & $\begin{array}{l}\text { Korean } \\
\text { Wave } 5\end{array}$ & $\begin{array}{l}\text { Korean } \\
\text { Wave } 6\end{array}$ & $\begin{array}{c}\text { Korear } \\
\text { Wave }\end{array}$ \\
\hline \multirow{3}{*}{$\begin{array}{l}\text { Korean } \\
\text { Wave } 1\end{array}$} & Pearson & 1 & $.708^{\star *}$ & $.519^{* *}$ & $.603^{* *}$ & $.510^{\star *}$ & $.298^{\star *}$ & $.757^{* *}$ \\
\hline & $\begin{array}{l}\text { Sig. (2- } \\
\text { tailed) }\end{array}$ & & .000 & .000 & .000 & .000 & .000 & .000 \\
\hline & $\begin{array}{c}\mathrm{N} \\
\text { Pearson }\end{array}$ & 148 & 148 & 148 & 148 & 148 & 148 & 148 \\
\hline Wave 2 & $\begin{array}{l}\text { Correlation } \\
\text { Sig. (2- } \\
\text { tailed) }\end{array}$ & $\begin{array}{c}.708^{* *} \\
.000\end{array}$ & 1 & $\begin{array}{c}.698^{* *} \\
.000\end{array}$ & $\begin{array}{l}.640^{* *} \\
.000\end{array}$ & $\begin{array}{c}.607^{* *} \\
.000\end{array}$ & $\begin{array}{l}.376^{* *} \\
.000\end{array}$ & $\begin{array}{c}.855^{\star *} \\
.000\end{array}$ \\
\hline Korean & $\underset{\text { Pearson }}{N}$ & 148 & 148 & 148 & 148 & 148 & 148 & 148 \\
\hline \multirow[t]{2}{*}{ Wave 3} & $\begin{array}{l}\text { Correlation } \\
\text { Sig. (2- } \\
\text { tailed) }\end{array}$ & $\begin{array}{l}.519^{* *} \\
.000\end{array}$ & $\begin{array}{l}.698^{* *} \\
.000\end{array}$ & 1 & $\begin{array}{l}.545^{\star *} \\
.000\end{array}$ & $\begin{array}{l}.780^{* *} \\
.000\end{array}$ & $\begin{array}{l}.542^{* *} \\
.000\end{array}$ & $\begin{array}{c}.879^{* *} \\
.000\end{array}$ \\
\hline & $\mathrm{N}$ & 148 & 148 & 148 & 148 & 148 & 148 & 148 \\
\hline
\end{tabular}

From table 1 above, it can be seen that all question items used in the independent variable (Korean Wave) have an rcount value that is greater than the rtable value, which is 0.1614 . So that all Korean Wave questions are valid and can be used as research measuring tools.

\subsection{Bound Variable Validity Test}

The results of the independent variable validity test can be seen in table 2 and table 3 below.

Table 2. Bound Variable Validity Test Results (Export)

\begin{tabular}{cccccc}
\hline & & Export 1 & Export 2 & Export 3 & Export 4 \\
\hline Export 1 & Pearson Correlation & 1 & $.753^{* *}$ & $.776^{* *}$ & $.647^{* *}$ \\
& Sig. (2-tailed) & & .000 & .000 & .000 \\
Export 2 & $N$ & 148 & 148 & 148 & 148 \\
& Pearson Correlation & $.753^{* *}$ & 1 & $.873^{* *}$ & $.751^{* *}$ \\
& Sig. (2-tailed) & .000 & 148 & .000 & .000 \\
& $\mathrm{~N}$ & 148 & & 148 & 148 \\
\hline
\end{tabular}




\begin{tabular}{cccccc}
\hline Export 3 & Pearson Correlation & $.776^{* \star}$ & $.873^{* *}$ & 1 & $.722^{* *}$ \\
& Sig. (2-tailed) & .000 & .000 & & .000 \\
& $N$ & 148 & 148 & 148 & 148 \\
Export 4 & Pearson Correlation & $.647^{\star \star}$ & $.751^{\star \star}$ & $.722^{\star *}$ & 1 \\
& Sig. (2-tailed) & .000 & .000 & .000 & \\
& $N$ & 148 & 148 & 148 & 148 \\
\hline
\end{tabular}

Source: Research results (processed, 2017)

Table 3. Bound Variable Validity Test Results (Tourism)

\begin{tabular}{cccccc}
\hline & & Tourism 1 & Tourism 2 & Tourism 3 & Tourism 4 \\
\hline Tourism 1 & Pearson Correlation & 1 & $.771^{* *}$ & $.648^{\star *}$ & $.437^{\star *}$ \\
& Sig. (2-tailed) & & .000 & .000 & .000 \\
Tourism 2 & Nearson Correlation & $.771^{\star *}$ & 148 & 148 & 148 \\
& Sig. (2-tailed) & .000 & 1 & $.663^{\star *}$ & $.455^{\star *}$ \\
& N & 148 & 148 & .000 & .000 \\
& & & & 148 & 148 \\
\hline
\end{tabular}

Table 4. connection

\begin{tabular}{cccccc}
\hline & & Tourism 1 & Tourism 2 & Tourism 3 & Tourism 4 \\
\hline Tourism 3 & Pearson Correlation & $.648^{\star \star}$ & $.663^{\star \star}$ & 1 & $.605^{\star \star}$ \\
& Sig. (2-tailed) & .000 & .000 & .000 & 148 \\
Tourism 4 & 148 & 148 & 148 & 1 \\
& Pearson Correlation & $.437^{\star *}$ & $.455^{\star \star}$ & $.605^{\star \star}$ & .000 \\
& Sig. (2-tailed) & .000 & .000 & 148 & 148 \\
\hline \multirow{2}{*}{ N } & 148 & 148 & 148
\end{tabular}

${ }^{\star *}$. Correlation is significant at the 0.01 level (2-tailed). Source: Research results (processed, 2017)

\subsection{Reliability Test}

Reliability test was conducted to see whether the research instrument used was reliable and trustworthy. Because a reliable and trustworthy research instrument will produce research that has a high level of confidence. The criteria for determining reliability are as follows:

a. If the value of the reliability coefficient (Cronbach's Alpha) $>0.6$ then the research instrument is declared reliable.

b. If the value of the reliability coefficient (Cronbach's Alpha) $<0.6$ then the research instrument is declared reliable.

a. Free Variable Reliability Test

The results of the independent variable reliability test can be seen in table 5 below this.

Table 5. Independent Variable Reliability Test Results

\begin{tabular}{cc}
\hline Cronbach's Alpha & N of Items \\
\hline .876 & 6 \\
\hline \multicolumn{2}{c}{ Source: Research results (processed, 2017) }
\end{tabular}

From table 5, it can be seen that the Korean Wave variable has an $r$ alpha that is greater than the standard $r$ value of 0.6 , which is 0.876 . Therefore, the Korean Wave variable is declared reliable.

b. Bound Variable Reliability Test

The results of the reliability test of the dependent variable can be seen in table 6 this.

Table 6. Bound Variable Reliability Test Results

\begin{tabular}{cc}
\hline Cronbach's Alpha & N of Items \\
\hline .895 & 15 \\
\hline Source: Research results (processed, 2017)
\end{tabular}


From table 6 above, it can be seen that the Nation brand variable has an $r$ alpha that is greater than the standard $r$ value of 0.6 which is 0.895 . Therefore, the Nation brand variable is declared reliable.

\subsection{Data analysis technique}

\section{a. Classic assumption test}

The classic assumption test used is the normality test. This test is used to see whether in the regression model, the dependent variable and the independent variable have a normal distribution. The normal distribution forms a straight diagonal graph, plotting the residual data will compare it with the diagonal line. If the distribution is normal, then the line depicting the normal line will follow the actual line. The way of making decisions on the plot method is:

1) If the data spreads around the diagonal line and follows the direction of the diagonal line, then the regression line model meets the assumption of normality.

2) If the data spreads far from the diagonal line or does not follow the direction of the diagonal line, then the regression model does not meet the assumption of normality.

The results of the normality test can be seen in Figure 1 below.

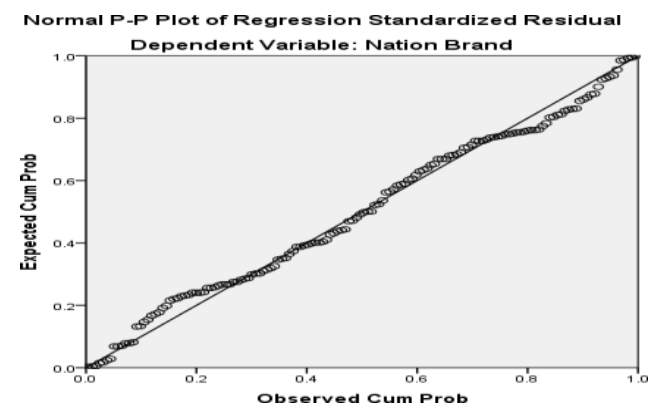

Figure 1. Normality Test Result

Source: Research results (processed, 2017)

Judging from the normal graph display in Figure 4.1 above, the data points are spread around the diagonal line and follow the direction of the diagonal line of the P-Plot graph. This pattern indicates that each variable has a normal distribution. So it can be concluded that the regression model meets the assumption of normality.

\section{b. Simple Linear Regression Analysis}

In this section, a simple linear regression analysis is carried out to determine the extent to which the variable $X$, namely the Korean Wave, affects the variable $Y$, namely the Nation brand. The results of simple linear regression analysis can be seen in the table 4.34 below.

\begin{tabular}{|c|c|c|c|c|c|c|}
\hline & \multirow[t]{2}{*}{ Model } & \multicolumn{2}{|c|}{ Unstandardized Coefficients } & \multirow{2}{*}{$\begin{array}{c}\text { Standardized } \\
\text { Coefficients } \\
\text { Beta } \\
\end{array}$} & \multirow[t]{2}{*}{$\mathrm{t}$} & \multirow[t]{2}{*}{ Sig. } \\
\hline & & $\mathrm{B}$ & Std. Error & & & \\
\hline \multirow[t]{2}{*}{1} & (Constant) & 22.803 & 2,389 & .700 & 9.547 & .000 \\
\hline & Korean Wave & 1.261 & .107 & & 11.842 & .000 \\
\hline
\end{tabular}

a. Dependent Variable: Nation Brand

Source: Research results (processed, 2017)

From table 7 above, a regression equation model is obtained :

$\mathrm{Y}=22,083+1.261 \mathrm{X}$ 


\section{b. Hypothesis testing}

Hypothesis testing is conducted to analyze whether the hypothesis is accepted or rejected.

The hypotheses in this study are:

H0: The Korean Wave has no significant effect on the Nation brand of South Korea.

$\mathrm{Ha}$ : The Korean wave has a significant effect on the Nation brand of South Korea.

\section{c. Partial Test (t-test)}

Based on the results of primary data processing, the partial test results are obtained as outlined in table 8 below. The confidence level used is $99 \%$.

Table 8. Partial Test Results (t-test)

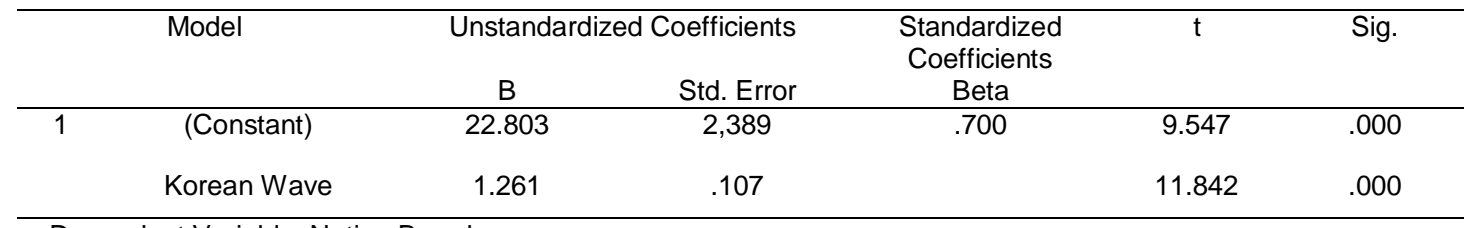

a. Dependent Variable: Nation Brand

The value of $t$ table with $99 \%$ confidence level for 148 respondents is 2,352. Based on the results of data processing in table 4.35 above, it is known that the t-count value is 11.842 . So the value of $t$ count $>t$ table, which means that the Korean Wave has a positive effect on the Nation brand. From the table, it is also known that the significance value (Sig.) is greater than 0.05 , which is 0.000 . This means that the Korean Wave has a significant effect on the Nation brand, which means $\mathrm{Ha}$ is accepted and $\mathrm{HO}$ is rejected.

\section{d. Coefficient of Determination Test (R2)}

The test used to test the hypothesis is the coefficient of determination test (R2). The value of the coefficient of determination is between 0 and 1 . Based on the results of primary data processing, the output in table 4.36 is obtained, as follows:

\begin{tabular}{ccccc} 
& \multicolumn{3}{c}{ Table 9. Coefficient of Determination Test Results (R2) } \\
\hline Model & $\mathrm{R}$ & $\mathrm{R}$ Square Adjusted R Square & $\begin{array}{c}\text { Std. Error of the } \\
\text { Estimate }\end{array}$ \\
\hline 1 & $.700 \mathrm{a}$ & .490 & .486 & 7.269
\end{tabular}

a. Predictors: (Constant), Korean Wave

Based on table 9 above, it is known that the correlation coefficient $(R)$ which shows the relationship between the Korean Wave and the Nation brand is 0.700 . The model's ability to explain the variation in the value of the dependent variable (Nation Brand) can be seen in the Adjusted $R$ Square, which is 0.486 . This shows that the variation up and down the value of the Nation brand which is influenced by the Korean Wave is $48.6 \%$, while the remaining $51.4 \%$ is influenced by other variables not included in this study. $R$ value of 0.700 indicates that the correlation or relationship between the independent variable (Korean Wave) to the dependent variable (Nation brand) is very strong.

\section{CONCLUSION}

Based on the results of research conducted on students of the Faculty of Social and Political Sciences, University of North Sumatra (FISIP USU) regarding the influence of the Korean Wave on the Nation brand of South Korea, the following conclusions were obtained.

Based on the results of the partial test or $t$ test, it is known that the Korean Wave has a positive and significant influence on the Nation brand of South Korea. Based on the results of the coefficient of determination test, it is also known that the correlation between the Korean Wave and the South Korean Nation brand is in the very strong category. However, the influence of the Korean 
Wave on the Nation brand is $48.6 \%$, which means that there is still an influence of $51.4 \%$ from other variables not examined in this study. This shows that although the Korean Wave has a significant influence on the Nation brand, the Korean Wave is not the most influential factor in the South Korean Nation brand.

The positive and significant influence of the Korean Wave on the South Korean Nation Brand on the students of the Faculty of Social and Political Sciences, North Sumatra University, indicates that South Korea through its popular culture, in this case Korean music and drama, has succeeded in gaining positive perceptions of USU FISIP students towards the Nation. the brand. In general, students of the Faculty of Social and Political Sciences, University of North Sumatra (FISIP USU) have positive perceptions of South Korean products, tourism, economics and social life due to the influence of the spread of Korean popular culture in this case Korean music and drama (Korean Wave).

\section{REFERENCES}

Armstrong, Gary, Philip Kotler dan Geoffrey da Silva. 2006. Marketing: An Introduction An Asian Perspective. Singapore: Prentice Hall.

Assauri, Sofjan. 2007. Manajemen Pemasaran. Jakarta: PT. Raja Grafindo Persada. Ferrinadewi, Erna. 2008. Merek dan Psikologi Konsumen. Yogyakarta: Graha IImu.

Hasan, Ali. 2015. Tourism Marketing. Yogyakarta: Center for Academic Publishing Service.

Hong, Euny. 2016. Korean Cool: Strategi Inovatif di Balik Ledakan Budaya Pop Korea. Jakarta: Bentang Pustaka.

Keith, Dinnie. 2008. Nation Branding: Concept, Issues, Practice. USA: Elsevier. Kotler, Philip dan Kevin Lane Keller. 2009. Manajemen Pemasaran, Edisi Ketiga Belas Jilid I. Jakarta: Penerbit Erlangga.

Moilanen, Teemu dan Seppo Rainisto. 2009. How to Brand Nations, Cities and Destinations: A Planning Book for Place Branding. New York: Palgrave Macmillan.

Priyono. 2016. Metode Penelitian Kuantitatif. Sidoarjo: Zifatama Publishing. Sangadji, Mamang Etta dan Sopiah. 2010. Metodologi Penelitian: Pendekatan

Praktis Dalam Penelitian. Yogyakarta: Penerbit Andi.

Sunyoto, Danang. 2013. Metode dan Instrumen Penelitian (Untuk Ekonomi dan Bisnis). Yogyakarta: CAPS (Center for Academic Publishing Service).

Tjiptono, Fandi. 2011. Manajemen dan Strategi Merek. Yogyakarta: Penerbit Andi.

Temporal, Paul. 2001. Branding In Asia: The Creation, Development, and Management of Asian Brands for the Global Market. Singapore: John Wiley \& Sons (Asia) Pte Ltd.

Wulansari Devi. 2016. Kebijakan Sistem Penerimaan Peserta Didik Baru Di Sekolah Menengah Kejuruan Negeri 1 Cangkringan Sleman Yogyakarta. Skripsi. Program sarjana Administrasi Pendidikan. Universitas Negeri Yogyakarta. Yogyakarta.

Peraturan pemerintah RI Nomor 17 Tahun 2010 tentang pengelolaan dan penyelenggaraan pendidikan.

Undang-undang Nomor 20 tahun 2003 tentang sistem pendidikan Naisonal Peraturan pemerintah RI Nomor 17 Tahun 2010 pasal 74 (ayat 1 dan 2) dan pasal 82 (ayat 1 dan 2) tentang penerimaan peserta didik pada satuan pendidikan dasar/menengah.

Anholt, Simon. What Is a Nation Brand. Superbrands. 2005. Three Interlinking Concepts: Intellectual Property, Nation Branding and Economic Development. WIPO International Seminar on Intellectual Property and Development. Geneva.

Dong-Hun, Lee. 2010. Nation Branding Korea. SERI. Korea. Muhammad, Wahyudi Akmaliah. 2008. Fenomena Hallyu (Gelombang Korean- Pop/K- Pop) dan Dampaknya Di Indonesia.

Prost, Olivia-Ih. 2014. South Korea Trying To Improve Its Nation Brand. Asia Centre. Paris.

Anholt, Simon. 2007. Competitive Identity: The New Brand Management for Nations, Cities, and Regions. Journal of Brand Management. 2013. Beyond the Nation Brand: The Role of Image and Identity in International Relations. Exchange: The Journal of Public Diplomacy. Vol .2, hal 6-12. 2008 Editorial 'Nation Branding' in Asia. Place Branding and Public Diplomacy. Vol. 4, hal 265-269.

$\bar{C}$ Cheng, Li-Chih. 2008. The Korea Brand: The Cultural Dimension of South Korea's Branding Project in 2008. John Hopkins University. Hal 73-85.

Dinnie, Keith, T.C. Melewar, Kai-Uwe Seidenfuss, dan Ghazali Musa. 2010. Nation Branding and Integrated Marketing Communications: an ASEAN perspective. International Marketing Review. Vol. 27 No.4, hal 388-401.

Dinnie, Keith. 2010. Repositioning the Korea Brand to a Global Audience: Challenges, Pitfalls, and Current Strategy. Korean Economic Institute. Vol.4 No. 9, Hal 1-7. 
Fan, Ying. 2006. Branding The Nation: Towards A Better Understanding. Brunei Business School. Brunei University.

Irwansyah. 2013. Menginisiasi Nation Branding Indonesia Menuju Daya Saing Bangsa. Jurnal IImu Komunikasi. Vol.11 No.1. Hal 80-91.

Jannah, Bidratul, Zainul Arifin, dan Andriani Kusumawati. 2014. Jurnal Administrasi Bisnis. Bandung: Universitas Brawijaya.

Jin, Dal Yong. 2012. The New Korean Wave in The Creative Industry: Hallyu 2.0 II Journal. Michigan: University of Michigan. Hal 3-7.

Jin. 2012. Fenomena Hallyu (Gelombang Korean-Pop/K-Pop) dan Dampaknya di Indonesia. Jurnal Masyarakat dan Budaya. Vol. 14 No1, hal 201-212

Lee, Sue Jin. 2011. The Korean Wave: The Seoul of Asia. The Elon Journal of Undergraduate Research in Communications. Vol. 2 No.1, hal 85-92.

Ramadhan, Abdurrahman Hikmah, Suharyono dan Srikandi Kumadji. 2015. Jurnal Administras Bisnis. Malang: Universitas Brawijaya.

Ramadhan, Ananda. 2015. Pengaruh Terpaan Tayangan Korean Wave (Demam Korea) Terhadap Gaya Hidup Mahasiswi Fakultas IImu Sosial dan IImu Politik Universitas Sumatera Utara. Medan: Universitas Sumatera Utara.

Sepriadi, Suhendra. 2015. Pengaruh Country of Origin Terhadap Perceived Value Dengan Consumer Ethnocentrism Sebagai Variabel Moderator. Medan: Universitas Sumatera Utara.

Szondi, Gyorgi. 2008. Public Diplomacy and Nation Branding: Conceptual Similarities and Differences. Netherlands Institute of International Relations 'Clingendael'. Hal 1-42.

Utami, Sri dan Vanessa Gaffar. 2014. Pengaruh Strategi Nation Branding "Wonderful Indonesia" Terhadap Proses Keputusan Berkunjung Wisatawan Australia Ke Indonesia. Tourism and Hospitality Essentials Journal. Bandung: UPI. 